\title{
Process optimization and eco-friendly/greener synthesis of some n-aryl/heteryl acetoacetamides
}

\author{
*Kalam Sirisha, Injimuri Rajyalaxmi, Sairem Olivia \\ Medicinal Chemistry Research Division, Vaagdevi College of Pharmacy, Kishanpura, Hanamkonda, A. P., India
}

\begin{abstract}
$\mathrm{N}$-aryl/heteryl acetoacetamides are the intermediates used in the synthesis of various heterocyclic compounds like 1,4dihydropyridines, pyrimidines etc. Three different substituted N-aryl/heteryl acetoacetamide derivatives (I-III) have been prepared from the reaction of ethylacetoacetate and three different aryl/heteryl primary amines under solvent free conditions using potassium tert-butoxide as catalyst. The reactions were carried out by two different methods (viz., Conventional and Microwave irradiation) and they are simple, eco-friendly and economical. All reactions were processed for optimization with different ratios of aryl/heteryl amine and ethylacetoacetate like1:1,1:1.2,1:1.4,1:1.6,1:1.8,1:2 and a comparison was made between the percentage yields with each ratio. Highest percentage yield was observed with 1:1.8 ratio for I \& II and 1:1.6 ratio for III in both the methods. However, the microwave irradiation method was found to be superior to the conventional method. The newly synthesized compounds have been purified by recrystallization and characterized by physical and spectral data.
\end{abstract}

Key Words: Ethylacetoacetate, potassium tert-butoxide, optimization, microwave irradiation, amine, catalyst.

\section{INTRODUCTION}

$\mathrm{N}$-aryl/heteryl acetoacetamides are intermediate compounds used in the synthesis of various heterocyclics exhibiting a wide range of pharmacological activities (Chang et al., 2001). In particular, they play key role as intermediates in the synthesis of pyridines and pyrimidines (Dyachenko, 2005; Habashi et al., 1986; Lebed et al., 2012; Kumar et al., 2009; Riad et al., 1989; Sadek et al., 2011; Viale et al., 2011; Yadav et al., 2003; Yadav et al., 2011). They are prepared by the two component reaction of alkyl acetoacetate and different aromatic /hetero aromatic amines (Desai et al., 2001). Reaction of acetoacetamides with various aldehydes in presence of ammonia source yield different derivatives of pyridines and pyrimidines having different pharmacological activities like antibacterial, antitubercular (Sirisha et al., 2011), anticancer (Sirisha et al., 2010), antioxidant (Velena et al., 1999) etc. The present study deals with a new and better protocol to prepare some $\mathrm{N}$-aryl/heteryl acetoacetamides (I-III). Solvent free conventional and microwave irradiation methods using potassium tert-butoxide as catalyst were employed for the synthesis of $\mathrm{N}$-aryl/heteryl acetoacetamides. The reactions are simple, eco-friendly and cost effective. They have been optimized by both the methods. The parameters of interest were the concentration of reactants and time of reaction.

\section{MATERIALS AND METHODS}

\section{Materials}

Chemicals used in synthetic work were p-toluidine, $p$ chloroaniline, 2-aminopyridine, ethylacetoacetate, potassium tert butoxide. They were purchased from SD Fine Chem Limited, Mumbai and Sigma Aldrich, Mumbai. All the solvents used were of analytical grade and were obtained from E. Merck, Mumbai and SD Fine Chem Limited, Mumbai.

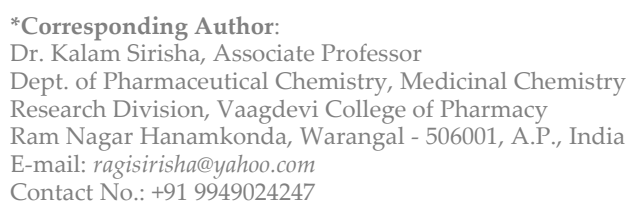

\begin{abstract}
Methods
Melting points were determined in open capillaries using Toshniwal electrical melting point apparatus (Toshniwal Instruments, Amjer, India) and are uncorrected. IR spectra were recorded on a Bruker FTIR spectrometer in $\mathrm{KBr}$ discs ${ }^{1} \mathrm{H}-\mathrm{NMR}$ spectra were recorded in $\mathrm{CDCl}_{3}$ with tetramethylsilane (TMS) as an internal standard on a Bruker 80 $\mathrm{MHz}$ FT-NMR (300 MHz) spectrometer (Bruker Bioscience, USA) and the chemical shifts are reported as $\delta$ (ppm). Mass spectra were recorded on a GC-MS QP-1100 Shimadzu instrument (70 eV; Shimadzu). A domestic LG Little Chef microwave oven (LG, India) was used for microwave irradiation. Reaction courses and product mixtures were routinely monitored by thin-layer chromatography (TLC) on precoated silica gel 60 F254 aluminum plates (Merck, Germany).
\end{abstract}

\section{General procedure for synthesis}

Conventional method

A mixture of an appropriate amine and ethyl acetoacetate in different ratios i.e., 1:1, 1:1.2, 1:1.4, 1:1.6, 1:1.8, 1:2 and a catalytic amount of potassium tert-butoxide was taken into a $250 \mathrm{~mL}$ RB flask. The reaction mixture was heated under reflux for $1-10 \mathrm{~h}$. The residue was cooled and triturated with dry ether. The product was filtered and washed with small portions of dry ether. Purification was effected by recrystallization from aqueous ethanol to obtain a colorless crystalline solid.

\section{Microwave method}

A mixture of an appropriate amine and ethyl acetoacetate in different ratios i.e., 1:1, 1:1.2, 1:1.4, 1:1.6, 1:1.8, 1:2 and a catalytic amount of potassium tert-butoxide was taken into a $250 \mathrm{~mL}$ Pyrex beaker with an inverted glass funnel and irradiated in a domestic microwave oven for 3-7 min with $30 \mathrm{~s}$ pulses at $480-640 \mathrm{~W}$ while monitoring the progress of the reaction by TLC. On completion of the reaction, the reaction mixture was cooled and triturated with ice-cold ether. The product separated was filtered, washed with small portions of ice cold ether and dried. 
Table 1: Physical data of $\mathrm{N}$-aryl/heterylacetoacetamides.

\begin{tabular}{ccccc}
\hline Code & R & $\begin{array}{c}\text { Molecular } \\
\text { formula }\end{array}$ & $\begin{array}{c}\text { Molecular } \\
\text { weight }\end{array}$ & $\begin{array}{c}\text { Melting } \\
\text { point }\left({ }^{\circ} \mathbf{C}\right)\end{array}$ \\
\hline I & 4-Chlorophenyl & $\mathrm{C}_{10} \mathrm{H}_{10} \mathrm{ClNO}_{2}$ & 211.64 & $115-118$ \\
II & 2-Pyridyl & $\mathrm{C}_{9} \mathrm{H}_{10} \mathrm{~N}_{2} \mathrm{O}_{2}$ & 178.19 & $114-116$ \\
III & 4-Methyl phenyl & $\mathrm{C}_{11} \mathrm{H}_{13} \mathrm{NO}_{2}$ & 191.23 & $78-80$ \\
\hline
\end{tabular}

Table 3: Reaction optimization data for N-(pyridin-2-yl)acetoacetamide (II).

\begin{tabular}{ccc|cc}
\hline \multirow{2}{*}{$\begin{array}{c}\text { 2-Aminopyridine: } \\
\text { Ethylacetoacetate }\end{array}$} & \multicolumn{2}{c|}{ Time } & \multicolumn{2}{c}{ \%ield } \\
\cline { 2 - 5 } & $\begin{array}{c}\text { Conventio- } \\
\text { nal heating }\end{array}$ & $\begin{array}{c}\text { MW irradia- } \\
\text { tion at 480W }\end{array}$ & $\begin{array}{c}\text { Conventio- } \\
\text { nal heating }\end{array}$ & $\begin{array}{c}\text { MW } \\
\text { irradiation }\end{array}$ \\
\hline $1: 1$ & $1 \mathrm{hr}$ & $4 \mathrm{mins}$ & 7.4 & 13.6 \\
$1: 1.2$ & $3.5 \mathrm{hrs}$ & $4 \mathrm{mins}$ & 8.6 & 18.7 \\
$1: 1.4$ & $4.5 \mathrm{hrs}$ & $4 \mathrm{mins}$ & 36 & 41 \\
$1: 1.6$ & $7 \mathrm{hrs}$ & $5 \mathrm{mins}$ & 38 & 44 \\
$1: 1.8$ & $10 \mathrm{hrs}$ & 6mins & 41 & 46 \\
$1: 2$ & $4 \mathrm{hrs}$ & $7 \mathrm{mins}$ & 7.3 & No yield \\
\hline
\end{tabular}

Table 2: Reaction optimization data for N-(4-Chlorophenyl)acetoacetamide (I).

\begin{tabular}{ccc|cc}
\hline \multirow{2}{*}{$\begin{array}{c}\text { 4-Chloroaniline: } \\
\text { Ethylacetoacetate }\end{array}$} & \multicolumn{2}{c|}{ Time } & \multicolumn{2}{c}{ \% Yield } \\
\cline { 2 - 5 } & $\begin{array}{c}\text { Conventio- } \\
\text { nal heating }\end{array}$ & $\begin{array}{c}\text { MW irradia- } \\
\text { tion at 640W }\end{array}$ & $\begin{array}{c}\text { Conventio- } \\
\text { nal heating }\end{array}$ & $\begin{array}{c}\text { MW } \\
\text { irradiation }\end{array}$ \\
\hline $1: 1$ & $1 \mathrm{hr}$ & 3mins & 16 & 44 \\
$1: 1.2$ & $2 \mathrm{hrs}$ & $3.5 \mathrm{mins}$ & 17 & 47 \\
$1: 1.4$ & $3.5 \mathrm{hrs}$ & $4 \mathrm{mins}$ & 42 & 53 \\
$1: 1.6$ & $5 \mathrm{hrs}$ & $4 \mathrm{mins}$ & 46 & 54.8 \\
$1: 1.8$ & $6 \mathrm{hrs}$ & 6mins & 51 & 56 \\
$1: 2$ & $8 \mathrm{hrs}$ & 7mins & 14 & 10 \\
\hline
\end{tabular}

Table 4: Reaction optimization data for N-(4-methyl phenyl)acetoacetamide (III)

\begin{tabular}{ccccc}
\hline \multirow{2}{*}{$\begin{array}{c}\text { 4-Toluidine: } \\
\text { Ethylacetoacetate }\end{array}$} & \multicolumn{2}{c}{ Time } & \multicolumn{2}{c}{ \%yield } \\
\cline { 2 - 5 } & $\begin{array}{c}\text { Conventio- } \\
\text { nal heating }\end{array}$ & $\begin{array}{c}\text { MW irradia- } \\
\text { tion at 640W }\end{array}$ & $\begin{array}{c}\text { Conventio- } \\
\text { nal heating }\end{array}$ & $\begin{array}{c}\text { MW } \\
\text { irradiation }\end{array}$ \\
\hline $1: 1$ & $5 \mathrm{hr}$ & $4 \mathrm{mins}$ & 9.4 & 13.2 \\
$1: 1.2$ & $6 \mathrm{hrs}$ & $5 \mathrm{mins}$ & 1.5 & 19.2 \\
$1: 1.4$ & $7 \mathrm{hrs}$ & $5 \mathrm{mins}$ & 2.5 & 51.36 \\
$1: 1.6$ & $7 \mathrm{hrs}$ & $5 \mathrm{mins}$ & 12.4 & 61.2 \\
$1: 1.8$ & $7 \mathrm{hrs}$ & 6mins & 9.94 & 40.9 \\
$1: 2$ & $6 \mathrm{hrs}$ & 7mins & 10.5 & 38.3 \\
\hline
\end{tabular}

Table 5: Spectral characterization data of $\mathrm{N}$-aryl/heteryl acetoacetamides (I-III).

\begin{tabular}{|c|c|c|c|c|}
\hline $\begin{array}{c}\text { Compound } \\
\text { (Molecular formula) }\end{array}$ & $\begin{array}{c}\text { IR } \\
(\mathrm{KBr}) v\left(\mathrm{~cm}^{-1}\right)\end{array}$ & $\begin{array}{c}{ }^{1} \mathrm{HNMR} \\
\left(\mathrm{CDCl}_{3}\right) \delta(\mathrm{ppm})\end{array}$ & $\begin{array}{c}\text { MS } \\
\mathrm{m} / \mathbf{z}(\%)\end{array}$ & Anal. calcd. (\%) \\
\hline $\begin{array}{l}\mathrm{N} \text {-(4-Chlorophenyl) } \\
\text { acetoacetamide (I) } \\
\mathrm{C}_{10} \mathrm{H}_{10} \mathrm{ClNO}_{2}\end{array}$ & $\begin{array}{c}3260(\mathrm{~N}-\mathrm{H}), 1645(\mathrm{C}=\mathrm{O}), \\
1514,1316(\mathrm{C}=\mathrm{N}) \\
1091(\mathrm{C}-\mathrm{Cl})\end{array}$ & $\begin{array}{l}\text { 2.28(s,3H,-COCH } 3), 3.24\left(\mathrm{~s}, 2 \mathrm{H},-\mathrm{COCH}_{2} \mathrm{CO}\right) \\
\text { 7.06-7.80(m,4H, Ar-H), } 9.76(\mathrm{~s}, 1 \mathrm{H}, \mathrm{CONH})\end{array}$ & $\begin{array}{c}211[\mathrm{M}+], 212(11), 213[\mathrm{M}+2] \\
214(3), 176,43(100)\end{array}$ & $\begin{array}{c}\mathrm{C}(56.75) ; \mathrm{H}(4.76) ; \\
\mathrm{N}(6.62) . \text { Found: } \\
\mathrm{C}(56.7) ; \mathrm{H}(4.8) ; \mathrm{N}(6.58)\end{array}$ \\
\hline $\begin{array}{l}\mathrm{N}-(2-P y r i d y l) \\
\text { acetoacetamide (II) } \\
\quad \mathrm{C}_{9} \mathrm{H}_{10} \mathrm{~N}_{2} \mathrm{O}_{2}\end{array}$ & $\begin{array}{c}3236(\mathrm{~N}-\mathrm{H}), 1660(\mathrm{C}=\mathrm{O}), \\
1154,779,705\end{array}$ & $\begin{array}{c}\left.\text { 2.33(s,3H,- } \mathrm{CH}_{3}\right), 3.62\left(\mathrm{~s}, 2 \mathrm{H},-\mathrm{CH}_{2}\right), 7.62- \\
7.70\left(\mathrm{dd}, 1 \mathrm{H}, \mathrm{H}_{4}-\text { pyridyl }\right), 8.10-8.29\left(\mathrm{~m}, 3 \mathrm{H}, \mathrm{H}_{3},\right. \\
\left.\mathrm{H}_{5} \& \mathrm{H}_{6}-\text { pyridyl }\right), 9.48(\mathrm{~s}, 1 \mathrm{H}, \mathrm{CONH})\end{array}$ & $\begin{array}{c}178(42)[\mathrm{M}+], 163(22), 135(12) \\
121(37), 106(21), 93(32)\end{array}$ & $\begin{array}{c}\mathrm{C}(60.65) ; \mathrm{H}(5.65) ; \\
\mathrm{N}(15.71) \cdot \text { Found: } \\
\mathrm{C}(60.62) ; \mathrm{H}(5.61) ; \mathrm{N}(15.68)\end{array}$ \\
\hline $\begin{array}{l}\mathrm{N} \text {-(4-Methylphenyl) } \\
\text { acetoacetamide (III) } \\
\mathrm{C}_{{ }_{11} \mathrm{H}_{13} \mathrm{NO}_{2}}\end{array}$ & $\begin{array}{c}3293(\mathrm{~N}-\mathrm{H}), 1657(\mathrm{C}=\mathrm{O}) \\
1162,1001,818,786\end{array}$ & $\begin{array}{c}2.29\left(\mathrm{~s}, 6 \mathrm{H}, 2 \times \mathrm{CH}_{3}\right), 3.54\left(\mathrm{~s}, 2 \mathrm{H},-\mathrm{CH}_{2}\right) \\
7.09-7.11\left(\mathrm{~d}, 2 \mathrm{H}, \mathrm{Ar}-\mathrm{H}_{3} \& \mathrm{H}_{5}\right), 7.39-7.40 \\
\left(\mathrm{~d}, 2 \mathrm{H}, \mathrm{Ar}-\mathrm{H}_{2} \& \mathrm{H}_{6}\right), 8.98(\mathrm{~s}, 1 \mathrm{H}, \mathrm{CO}-\mathrm{NH})\end{array}$ & $\begin{array}{c}191(26)\left[\mathrm{M}^{+}\right], 148(3), \\
133(73), 120(10), 107(76), 91(9), \\
77(53), 65(17), 43(100)\end{array}$ & $\begin{array}{c}\mathrm{C}(69.10) ; \mathrm{H}(6.80) \\
\mathrm{N}(7.32) \cdot \text { Found: } \\
\mathrm{C}(69.12) ; \mathrm{H}(6.83) ; \mathrm{N}(7.35)\end{array}$ \\
\hline
\end{tabular}

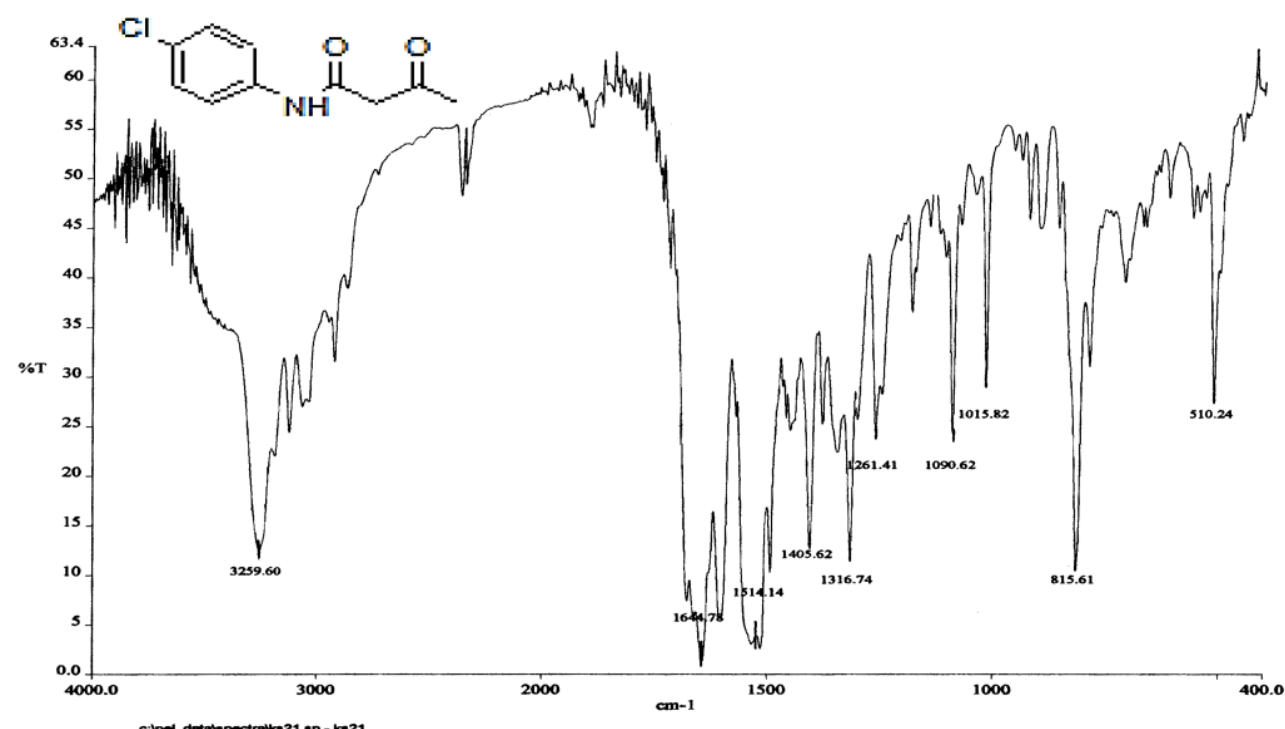

Figure 1: IR Spectrum of N-(4-chlorophenyl)acetoacetamide (I). 


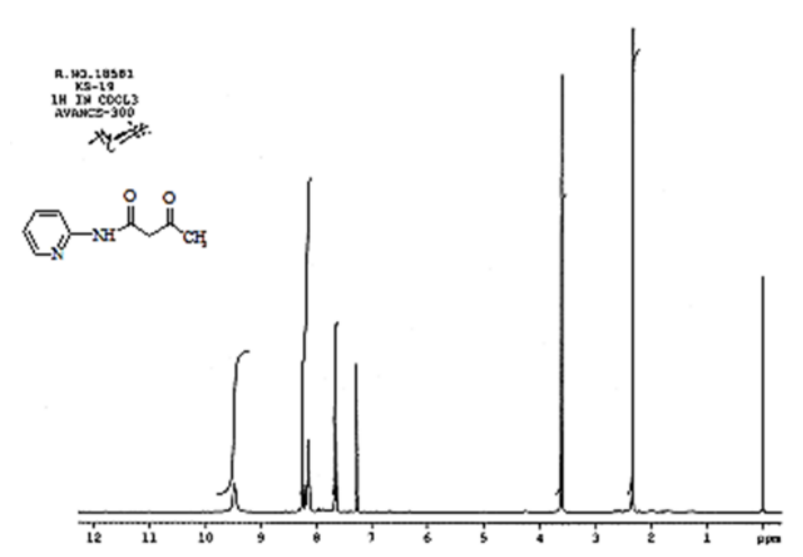

Figure 2: ${ }^{1} \mathrm{H}$ NMR Spectrum of N-(2-pyridyl)acetoacetamide (II).<smiles>[R]NC[O+]</smiles>

Ethylacetoacetate

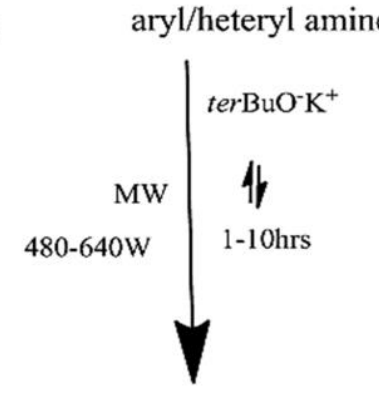

2-pyridyl, 4-chlorophenyl, p-toluidyl<smiles>[R]NC(=O)CC(C)=O</smiles>

$\mathrm{N}$-Aryl/heteryl acetoacetamide Scheme 1: Synthesis of $\mathrm{N}$-aryl/heteryl acetoacetamides.

National Centre for Mass Spectrometry

Indian Institute of Chemical Technology

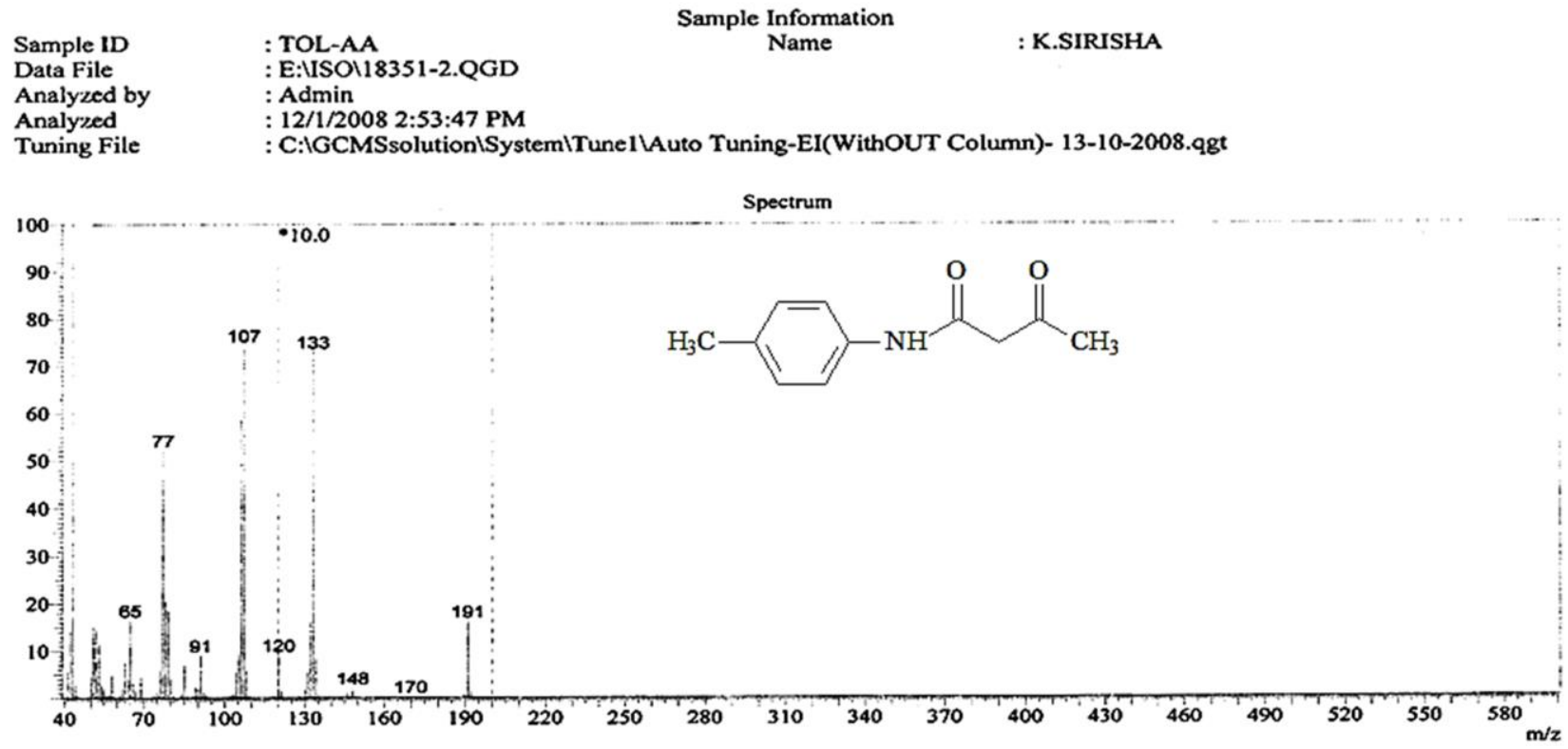

Figure 3: Mass Spectrum of N-(4-methylphenyl)acetoacetamide (III). 
Purification by recrystallization from aqueous ethanol afforded a colorless crystalline solid.

\section{RESULTS AND DISCUSSION}

$\mathrm{N}$-aryl/heteryl acetoacetamides (I-III) were synthesized from the reaction of three different aryl/heteryl primary amines and ethylacetoacetate in the presence of a trace of catalyst, potassium tert-butoxide under solvent free conditions by conventional and microwave irradiation methods (Scheme-1). The reactants were subjected to reflux for 1 to $10 \mathrm{~h}$ by conventional method while they were irradiated at $480-640 \mathrm{~W}$ for $3-7 \mathrm{~min}$ by microwave method to yield compounds I-III. The results are presented in tables 1-4.

Aryl/ heteryl amines and ethylacetoacetate were taken in various ratios like 1:1, 1:1.2, 1:1.4, 1:1.6, 1:1.8, 1:2 i.e., the concentration of ethylacetoacetate was gradually enhanced keeping the aryl/heteryl amines concentration constant. The percentage yield of N-substituted acetoacetamides was found to increase with increasing concentration of ethylacetoacetate considerably up to 1:1.6 [for N-(4-methyl phenyl) acetoacetamide (III)] and up to 1:1.8 [for N-(4-chloro phenyl) and N-(pyridin-2-yl) acetoacetamides (I\&II)], beyond which it decreased. Further the reaction times mentioned in the tables 2-4 illustrate the fact that for each ratio of amine and ethylacetoacetate there was no further progress in the reaction beyond the specified time. However, with an increase in the concentration of ethylacetoacetate the reaction times and the percentage yield were found to increase in all the three $\mathrm{N}$-substituted acetoacetamides. Amongst both the methods employed, the microwave irradiation method was found to be superior as it resulted in pure compounds in high yields within less time (3$7 \mathrm{~min})$. This is more clearly evident in case of N-(4-methyl phenyl) acetoacetamide (III). The structures of the newly synthesized compounds were confirmed from physical and spectral (IR, ${ }^{1} \mathrm{H}-\mathrm{NMR}$, Mass) data (table 5 and figure $1-3)$.

\section{CONCLUSION}

A new green synthetic methodology has been developed to generate $\mathrm{N}$-substituted acetoacetamides using potassium tert-butoxide as catalyst. The reactions were simple, economic and eco-friendly. Optimization of the reaction conditions using appropriate amine and ethyl acetoacetate revealed that an excess of ethyl acetoacetate resulted in improved yields with high purity. The reaction protocol involving Microwave irradiation was found to be superior to the Conventional heating and give highly encouraging results.

\section{ACKNOWLEDGEMENT}

The authors (IR \& SO) are thankful to the All India Council for Technical Education (AICTE), New Delhi, India for the award of GATE fellowship. All the authors are thankful to the management of Vaagdevi College of Pharmacy, A.P, India for providing the necessary facilities.

\section{REFERENCES}

Chang, J.Y., Kim, B. J., Park, C.R., Han, M.J., Kim, T.J., Yun, H. (2001). Synthesis and polymerization mechanism of bisacetoacetamides. Journal of Polymer Science, Part A: Polymer Chemistry, 39: 1456-1462. [DOI]

Desai, B, Sureja, D, Naliapara, Y, Shah, A, Saxena, A.K. (2001). Synthesis and QSAR Studies of 4-Substituted phenyl-2,6-dimethyl-3,5-bis-N(substituted phenyl)carbamoyl-1,4-dihydropyridines as potential antitubercular agents. Bioorg. Med. Chem. 9: 1993-1998. [DOI]

Dyachenko, V. D. (2005). Synthesis of Ammonium 5-Arylcarbamoyl-4heteryl-6-methyl-3-cyano-1,4-dihydropyridine-2-thiolates and 4Heteryl-5-carbamoyl-6-methyl-3-cyano-1,4-dihydropyridine-2selenolates. Russian Journal of General Chemistry, 75: 447-456. [DOI]

Habashi, A., Ibraheim, N.S., Mohareb, R.M., Fahmy, S.M. (1986). Reactions with Acetoacetanilide: New approaches for the Synthesis of Polyfunctionally Substituted Pyridine Derivatives. Liebigs Annalen der Chemie, 1986: 1632-1638. [DOI]

Lebed, P. S., Mozgovaya, N. G., Manoilenko, O.V., Tolmachova, V.S., Vovk, M.V. (2012). Synthesis of 1-substituted 5-acetyl (ethoxycarbonyl)-2,3dihydropyrazolo-[3,4-b]pyridin-3-ones. Chemistry of Heterocyclic Compounds, 48: 1058-1063. [DOI]

Kumar, P, Sankar, B. R., Nasir Baig G., R.B., Chandrashekaran, S. (2009). Novel Biginelli dihydropyrimidines with potential anticancer activity: A parallel synthesis and CoMSIA study. European Journal of Medicinal Chemistry, 44: 4192-4198. [DOI]

Riad, B.Y., Abdelhamid, A.O., Khalifa, F.A., Saleh, Y.E. (1989). Reactions with acetoacetanilide: Synthesis and antibacterial activity of some new pyran, pyrano[2,3-c]pyrazole and pyrano[2,3-c]-pyridine derivatives, Archives of Pharmacal Research, 12: 201-206. [DOI]

Sadek, B., Fahelelbom, K.M.S., Morusciag, L., Elz, S. (2011). Synthesis and Calcium Channel Blocking Activity of 1, 4-Dihydropyridine Derivatives Containing Ester Substitute and Phenyl Carbamoyl Group. American Journal of Applied Sciences 8: 303-309. [DOI]

Sirisha, K., Bikshapathi, G., Achaiah, G., Reddy, V. M. (2011). Synthesis, antibacterial and antimycobacterial activities of some new 4aryl/heteroaryl-2,6-dimethyl-3,5-bis-N-(aryl)-carbamoyl-1,4dihydropyridines. European Journal of Medicinal Chemistry, 46: 15641571. [DOI]

Sirisha, K., Achaiah, G., Reddy, V. M. (2010). Facile Synthesis and Antibacterial, Antitubercular, and Anticancer Activities of Novel 1,4Dihydropyridines, Arch. Pharm. Chem. Life Sci., 343: 342 - 352. [DOI]

Velena, A., Zilbers, J., Duburs, G. (1999) Derivatives of 1,4dihydropyridines as modulators of ascorbate-induced lipid peroxidation and high-amplitude swelling of mitochondria, caused by ascorbate, sodium linoleate and sodium pyrophosphate. Cell Biochem. Funct., 17: 237-252. [DOI]

Viale, M., Cordazzo, C., de Totero, D., Budriesi, R., Rosano, C., Leoni, A., Ioan, P., Aiello, C., Croce, M., Andreani, A., Rambaldi, M., Russo, P., Chiarini, A., Spinelli, D. (2011). Inhibition of MDR1 activity and induction of apoptosis by analogues of nifedipine and diltiazem: an in vitro analysis. Invest New Drugs, 29:98-109. [DOI]

Yadav, J. S., Reddy, B. V. S., Basak, A. K., Narsaiah, A. V. (2003). Threecomponent coupling reactions in ionic liquids: an improved protocol for the synthesis of 1,4-dihydropyridines. Green Chem, 5: 60-63. [DOI]

Yadav, D.K., Patel, R., Srivastava, V.P., Watal, G., Yadav, L.D.S. (2011) $\mathrm{LiBr}$ as an Efficient Catalyst for One-pot Synthesis of Hantzsch 1,4Dihydropyridines under Mild Conditions. Chin. J. Chem, 29: 118-122. [DOI] 